\title{
DINAMIKA PENGELOLAAN HUTAN BERSAMA MASYARAKAT (Studi Kasus Lmdh Tani Mukti Giri Jaya, Desa Mekarmanik, Kecamatan Cimenyan, Kabupaten Bandung)
}

\author{
THE DYNAMICS OF COMMUNITY FOREST MANAGEMENT \\ (Case Study of Lmdh Tani Mukti Giri Jaya, Mekarmanik Village, \\ Cimenyan District, Bandung Regency)
}

\author{
Fadil Bagaskara*, Ahmad Choibar Tridakusumah \\ Universitas Padjadjaran, Jl. Raya Bandung Sumedang KM. 21 \\ *Email: bagaskaraaf@gmail.com \\ (Diterima 14-1-2021; Disetujui 25-1-2021)
}

\begin{abstract}
ABSTRAK
Pengelolaan sumber daya alam menjadi peranan penting untuk menunjang kesejahteraan rakyat. Terdapat salah satu pengelolaan hutan bersama masyarakat melalui program pemerintah yang melibatkan pihak Perum Perhutani dengan masyarakat melalui lembaga masyarakat desa hutan. Berdasarkan hasil observasi, LMDH Tani Mukti Giri Jaya telah melalui berbagai keadaan lembaga yang kurang berjalan dengan semestinya hingga pembaharuan internal kepengurusan lembaga. Tujuan dari penelitian ini untuk mengetahui dinamika pengelolaan hutan bersama masyarakat di LMDH Tani Mukti Giri Jaya pada saat lembaga tersebut didirikan, saat ini, hingga rencana ke depan lembaga tersebut. Penelitian ini menggunakan metode kualitatif dengan teknik studi kasus. Hasil penelitian ini menunjukan permasalahan lembaga yang terjadi pada saat kepengurusan sebelumnya saat ini sudah mulai dibenahi dan melangkah untuk rencana jangka panjang dari lembaga tersebut. Dari aspek pemanfaatan hutan terdapat tiga poin utama yaitu sebagai faktor pendorong, dampak, dan kendala. Faktor pendorong memiliki sumber daya alam luas, dampak dari didirikannya lembaga tersebut masyarakat desa hutan mendapatkan akses untuk memanfaatkan lahan di kawasan Perum Perhutani, dan kendala dari program tersebut sering terjadi miss komunikasi internal antara lembaga dan kelompok tani. Aspek Kelembagaan menunjukan bahwa LMDH berkoordinasi dengan kantor desa dan Perum Perhutani untuk mengelola hutan bersama masyarakat.
\end{abstract}

Kata Kunci : Dinamika, LMDH, Pengelolaan Hutan, Perhutanan Sosial, PHBM

\section{ABSTRACT}

Natural resource management plays an important role in supporting people's welfare. There is a joint forest management with the community through a government program that involves Perum Perhutani and the community through forest village community institutions. Based on the results of observations, LMDH Tani Mukti Giri Jaya has gone through various institutional conditions that are not working properly to internal reform of the management of the institution. The purpose of this study was to determine the dynamics of community forest management at LMDH Tani Mukti Giri Jaya at the time the institution was founded, at this time, and the institution's future plans. This research uses qualitative methods with case study techniques. The results of this study indicate that the institutional problems that occurred during the previous management have started to be addressed and are taking steps for the long-term plans of the institution. From the aspect of forest utilization, there are three main points, namely as a driving factor, impact, and constraint. The driving factor has extensive natural resources, the impact of the establishment of this institution is that forest village communities have access to use land in the Perum Perhutani area, and the obstacles of this program are often miss internal communication between institutions and farmer groups. The institutional aspect shows that LMDH coordinates with the village office and Perum Perhutani to manage the forest together with the community.

Keywords: Forest Management, LMDH, PHBM, Social Forestry, The Dynamic 


\section{PENDAHULUAN}

Hutan Indonesia menjadi habitat bagi spesies flora dan fauna penting dunia. Secara ekonomi, sejak tahun 1980an, sumber daya hutan telah banyak memberi sumbangan terhadap peningkatan Produk Nasional Bruto (PNB) Indonesia yang cukup pesat (Nawir, 2008). Kawasan Hutan diklasifkasikan menjadi tiga fungsi, yaitu: Hutan Produksi (HP), meliputi areal seluas 68,8 juta hektar atau 57 persen dari Kawasan Hutan; Hutan Konservasi (HK), meliputi areal seluas 22,1 juta hektar atau 18 persen dari Kawasan Hutan (dengan tambahan 5,3 juta hektar dari kawasan konservasi perairan); dan Hutan Lindung yang memiliki fungsi perlindungan daerah aliran sungai (DAS) dan meliputi areal seluas 29,7 juta hektar atau 25 persen (Kementerian Lingkungan Hidup dan Kehutanan, 2018).

Setiap kelompok hutan di Indonesia umumnya memiliki keanekaragaman hayati yang tinggi. Sehubungan dengan pengelolaan hutan perlu dilakukan secara tepat agar keanekaragaman hayati yang tinggi tersebut tetap terjaga kelestariannya. Di setiap wilayah Indonesia memiliki keanekaragaman dari wilayahnya masing-masing, maka hal ini perlu disesuaikan pada pemanfaatan dalam pengelolaan wilayah tersebut.

Hutan di Pulau Jawa mempuyai peran sebagai penyangga ekosistem Pulau Jawa, di sisi lain hutan di pulau itu juga mengalami tekanan yang luar biasa dari masyarakat akibat perkembangan penduduk, sehingga hutan di Pulau Jawa juga dituntut untuk memberikan kontribusi ekonomi bagi masyarakat sekitar hutan dan berkontribusi terhadap pendapatan nasional. Di sisi lain hutan di Pulau Jawa juga harus berfungsi ekologis (Ekawati, et al, 2015).

Perum Perhutani membuat suatu konsep pengelolaan hutan bertujuan mensejahterakan masyarakat dan memperbaiki lahan-lahan hutan yang rusak agar fungsinya menjadi lebih optimal. Konsep pengelolaan hutan yang diciptakan oleh Perum Perhutani yaitu Pengelolaan Hutan Bersama Masyarakat (PHBM). PHBM dicanangkan oleh Perhutani untuk menjawab upaya meningkatkan kesejahteraan masyarakat dan perbaikan lingkungan hidup.

Dasar hukum PHBM adalah Surat Keputusan Direksi Perum Perhutani No.136/KPTS/DIR/2001 dan disempurnakan lagi melalui Surat Keputusan Direksi Perum Perhutani No. 682/KPTS/DIR/2009 bulan Juni. 2009 
tentang Pengelolaan Hutan Bersama Masyarakat (PHBM PLUS) PHBM Plus merupakan suatu sistem pengelolaan sumberdaya hutan dengan pola kolaborasi yang bersinergi antara Perum Perhutani dan masyarakat desa hutan atau para pihak yang berkepentingan dalam upaya mencapai keberlanjutan fungsi dan manfaat sumberdaya hutan yang optimal dan peningkatan Indeks Pembangunan Manusia (IPM) yang bersifat fleksibel, partisipatif, akomodatif, serta mempunyai prinsip bersama, berdaya, berbagi, dan transparan.

Kementerian Lingkungan Hidup dan Kehutanan (KLHK) mengeluarkan kebijakan perhutanan sosial dengan menerbitkan Peraturan Menteri No. 83 Th. 2016 dan Peraturan Menteri No. 39 Th. 2017 terkait perhutanan sosial di wilayah kerja Perum Perhutani. Perhutanan sosial di wilayah kerja Perum Perhutani dengan skema izin IPHPS (Izin Pemanfaatan Hutan Perhutanan Sosial) dilaksanakan pada hutan lindung atau hutan produksi. Perhutanan sosial di wilayah kerja Perum Perhutani dengan skema kemitraan kehutanan yang dilaksanakan di hutan lindung atau hutan produksi dan tidak terjadi kondisi sosial khusus, maka pemerintah dengan ini Kementerian Lingkungan Hidup dan
Kehutanan akan memberikan perlindungan dan pengakuan dalam bentuk penerbitan surat keputusan rekognisi dan perlindungan kemitraan kehutanan. Manfaat dari program perhutanan sosial di wilayah kerja Perum Perhutani diantaranya jangka waktu akses legal kelola lahan selama 35 tahun dan dapat diperpanjang berdasarkan hasil evaluasi yang dilakukan setiap 5 tahun. 2 insentif bagi hasil antara petani dan Perum Perhutani sesuai dengan peraturan No. 39 Th.2017.

Namun, keterlibatan masyarakat dalam pengelolaan hutan belum terkelola secara menyeluruh karena keterlibatan masyarakat belum jelas, terkadang terdapat konflik yang terjadi di daerah tersebut. Akibatnya hutan terlantar, lahan dibiarkan gundul. Dalam kondisi demikian, negara perlu hadir turun tangan memberikan solusi. Kelembagaan merupakan keseluruhan pola-pola ideal, organisasi, dan aktivitas yang berpusat di sekeliling kebutuhan dasar (DITJEN Perhutanan Sosial dan Kemitraan Lingkungan.2018).

Masyarakat yang telah lama tinggal di dalam kawasan secara turun temurun memenuhi kebutuhan hidupnya dari kawasan hutan, bertambahnya jumlah masyarakat menyebabkan kebutuhan 
sumberdaya kawasan yang dimanfaatkan juga semakin bertambah. Kondisi tersebut sering kali memicu terjadinya konflik dan menuntut adanya suatu solusi yang dapat mengakomodasi kepentingan berbagai pihak (Munawar 2019). Konflik dan ketidaksepakatan tentang siapa yang seharusnya mengontrol dan mengelola hutan di kawasan hutan negara merupakan sumber dari berbagai ketegangan serta struktur insentif yang mengarahkan para pemangku pihak bertindak merusak.

Dinas Kehutanan Jawa Barat telah mengupayakan lahan seluas 26 ribu hektar yang merupakan lahan milik Perum Perhutani. Hal ini diupayakan untuk mendongkrak roda atau melahirkan arus ekonomi bagi masyarakat desa hutan dengan memanfaatkan lahan garapan tersebut. Rosmaladewi, et al (2019) berpendapat diperlukan rehabilitasi dan konservasi hutan untuk meningkatkan daya dukung kawasan untuk berfungsi secara ekologis, ekonomi, dansosial. Upaya yang dilakukan adalah antara lain dengan membangun sistem kemitraan multipihak dalam pengelolaan hutan di cara partisipatif dan berkelanjutan. Pada tahap awal melalui lingkungan berbasis komunitas program pengelolaan.
Beberapa wilayah hutan di Jawa Barat pengelolaannya dengan mekanisme Pengelolaan Hutan Bersama Masyarakat (PHBM) melalui Lembaga Masyarakat Desa Hutan (LMDH). Lembaga Masyarakat Desa Hutan (LMDH) adalah satu lembaga yang dibentuk oleh masyarakat desa yang berada di dalam atau di sekitar hutan untuk mengatur dan memenuhi kebutuhannya melalui interaksi terhadap hutan dalam konteks sosial, ekonomi, politik dan budaya.

Suatu kelembagaan pertanian dibentuk selalu bertujuan untuk memenuhi berbagai kebutuhan petani sehingga lembaga mempunyai fungsi (Anantanyu 2011). LMDH Desa Tani Mukti Girijaya merupakan salah satu LMDH yang telah berdiri sejak 2011. Pendirian LMDH tersebut beriringan dengan pelaksanaan Pengelolaan Hutan Bersama Masyarakat (PHBM). Luas lahan Perum Perhutani yang dimanfaatkan oleh LMDH Desa Tani Mukti Girijaya seluas 596 hektar area yang beranggotakan 343 anggota di dalamnya terdapat 6 Kelompok Tani Hutan, diantaranya $5 \mathrm{KTH}$ komoditas kopi dan 1 KTH komoditas bambu.

Awal mula didirikan LMDH Tani Mukti Giri Jaya tujuannya untuk membantu dan memfasilitasi masyarakat 
dalam perizinan penggarapan lahan Perum Perhutani. Namun, seiring berjalannya waktu terdapat beberapa permasalahan yang mengakibatkan LMDH kurang berjalan optimal. Beberapa tahun kemudian LMDH terlahir kembali dengan visi baru yang sekarang mengacu pada administrasi lembaga, pendataan petani yang tersusun serta meningkatkan produksi dari masingmasing KTH. Kurangnya intensitas internal pada kepengurusan sebelumnya dapat berdampak seperti contohnya dalam pembukuan, struktur organisasi, pengembangan usaha, dan peningkatan jaringan usaha dapat kurang berjalan.

Nugroho (2011) mengemukakan terkait dengan Pengelolaan Hutan Bersama Masyarakat (PHBM) Melalui Penguatan Lembaga Masyarakat Desa Hutan (LMDH) mengungkapkan bahwa upaya penguatan kapasitas LMDH dapat diakukan melalui restrukturisasi kelembagaan LMDH dan pelatihan manajemen bagi pengurus dan anggota LMDH.

Berdasarkan uraian latar belakang yang telah dipaparkan, maka penelitian dinamika pengelolaan hutan bersama masyarakat di LMDH Tani Mukti Giri Jaya perlu untuk diteliti. Kajian dalam penelitian ini terdapat tujuan penelitian yaitu: mengidentifikasi pelajaran strategis mengenai faktor pendorong, dampak dan kendala dari pemanfaatan hutan di masa lalu melalui LMDH di lahan Perum Perhutani wilayah Desa Mekarmanik, mendeskripsikan peran LMDH Desa Tani Mukti Girijaya terhadap masyarakat Desa Mekarmanik, dan diperolehnya rencana LMDH di Desa Mekarmanik.

\section{METODE PENELITIAN}

Penelitian dilaksanakan pada bulan Oktober-Desember 2020 di Desa Mekarmanik Kecamatan Cimenyan Kabupaten Bandung, Jawa Barat. Lokasi dipilih karena di Desa Mekarmanik terdapat lahan hutan Perum Perhutani dan terdapat LMDH. Pertimbangan lainnya memilih LMDH Tani Mukti Giri Jaya karena terdapat kekosongan ketua di lembaga tersebut.

Penelitian menggunakan metode kualitatif. Data yang digunakan adalah data primer yang berasal dari wawancara mendalam dengan informan. Selain itu terdapat data sekunder yang bersumber dari lembaga, buku, jurnal, dan media informasi lainnya yang berhubungan dengan penelitian.

Informan dalam penelitian ini adalah pengurus $\mathrm{LMDH}$, mantan pengurus LMDH, perangkat desa, tokoh 
masyarakat, Ketua KRPH Arcamanik, dan mantan ketua KRPH Arcamanik.

Teknik penentuan informan dilakukan dengan teknik bola salju (snowball). Teknik pengumpulan data pada penelitian terdapat: observasi, wawancara mendalam, triangulasi data, studi dokumentasi, dan studi kepustakaan. Teknik analisis dan pengolahan data dengan reduksi data, display data, dan kesimpulan data.

\section{HASIL DAN PEMBAHASAN}

\section{Keadaan Umum Lokasi Penelitian}

Desa mekarmanik merupakan salah satu desa di Jawa Barat berlokasi di Kecamatan Cimenyan Kabupaten Bandung. Luasan desa 790,31 ha dengan ketinggian tanah 600-1.200 dpl. Rata-rata curah hujan per tahun Desa Mekarmanik $2.100 \mathrm{~mm}$. Sedangkan, luasan hutan di desa mekarmanik hampir separuh dari luasan desa tersebut. Secara administrasi terdiri atas 16 RW, 59 RT. Berdasarkan luas pembagian wilayah desa:

a) Sebelah Utara: Desa Sunten Jaya, Kecamatan Lembang.

b) Sebelah Selatan: Desa Sindang Laya, Kecamatan Cimenyan.

c) Sebelah Timur: Desa Girimekar, Kecamatan Cilengkrang. d) Sebelah Barat: Desa Cikadut, Kecamatan Cimenyan.

Berdasarkan orbitasi, jarak Desa Mekarmanik menuju ibu kota kecamatan sebesar $11 \mathrm{~km}$, jarak menuju Soreang sebagai ibu kota Kabupaten sebesar 34 km, jarak menuju Kota Bandung sebagai ibu kota provinsi sebesar $18 \mathrm{Km}$, jarak menuju DKI Jakarta sebagai ibu kota negara adalah $180 \mathrm{Km}$. Menurut Setiawan dalam Farida (2013), dalam ruang pedesaan, aksesibilitas sangat tertarik dengan kebutuhan dasar yang secara tidak langsung berhubungan dengan aspek kesejahteraan sosial dan aspek ekonomi.

Di Desa Mekarmanik saat ini, masih tidak terdapat angkutan transportasi umum bagi masyarakat untuk mempermudah. Selain itu, terdapat beberapa jalan di desa yang perlu diperbaiki. Penduduk Desa Mekarmanik pada tahun 2020 yaitu berjumlah 8.643 orang yang terdiri atas 4.388 laki-laki dan 3.255 perempuan, sedangkan kepadatan sebesar 578,31 orang $/ \mathrm{km} 2$.

Menurut Undang-undang No. 20 Tahun 2003 Tentang Sistem Pendidikan Nasional, jenjang pendidikan dibagi menjadi tiga yaitu pendidikan dasar (SD, SLTP), pendidikan menengah (SLTA) dan pendidikan tinggi (Diploma, Sarjana, 
Magister, Spesialis dan Doktor). Tingkat pendidikan di Desa Mekarmanik dapat dilihat pada Tabel 1.

Tabel 1. Tingkat Pendidikan Masyarakat Desa Mekarmanik

\begin{tabular}{clcc}
\hline No. & \multicolumn{1}{c}{$\begin{array}{c}\text { Tingkat } \\
\text { Pendidikan }\end{array}$} & $\begin{array}{c}\text { Laki- } \\
\text { laki }\end{array}$ & Perempuan \\
\hline 1. & Tamat SD & 931 & 899 \\
2. & Tamat SMP & 207 & 200 \\
3. & $\begin{array}{l}\text { Tamat } \\
\text { SMA/sederajat }\end{array}$ & 167 & 109 \\
4. & $\begin{array}{l}\text { Tamat } \\
\text { D1/sederajat }\end{array}$ & 2 & 3 \\
5. & $\begin{array}{l}\text { Tamat } \\
\text { D2/sederajat }\end{array}$ & 3 & 4 \\
6. & $\begin{array}{l}\text { Tamat } \\
\text { D3/sederajat }\end{array}$ & 4 & 4 \\
7. & Tamat S1/sederajat & 6 & 8 \\
8. & Tamat S1/sederajat & 2 & 1 \\
\hline & $\quad$ Jumlah & 1332 & 1228 \\
\hline
\end{tabular}

Sumber: Prodeskel, 2020

Berdasarkan Tabel 1, dapat dilihat bahwa tingkat pendidikan di Desa Mekarmanik secara umum didominasi oleh pendidikan lulusan Sekolah Dasar sejumlah 1830. Kondisi masyarakat Desa Mekarmanik dalam mendapatkan mata pencaharian relatif berbeda-beda sebagaimana terlihat pada Tabel 2 .

Tabel 2. Mata Pencaharian Masyarakat Desa Mekarmanik

\begin{tabular}{clcc}
\hline No. & $\begin{array}{c}\text { Jenis } \\
\text { Pekerjaan }\end{array}$ & $\begin{array}{c}\text { Laki- } \\
\text { laki }\end{array}$ & Perempuan \\
\hline 1. & Petani & 62 & 2 \\
2. & Buruh Tani & 65 & 2 \\
3. & Pegawai Negeri & 8 & 7 \\
& Sipil & & \\
4. & Wiraswasta & 145 & 2 \\
5. & Pedagang & 22 & 0 \\
& Keliling & & \\
6. & Karyawan & 115 & 0 \\
& Swasta & & \\
7. & Supir & 52 & 0 \\
8. & TNI & 1 & 0 \\
9. & POLRI & 1 & 0 \\
\hline
\end{tabular}

Sumber: Prodeskel, 2020
Tabel 2 menunjukan bahwa sektor pertanian menjadi salah satu sektor yang menampung mata pencaharian masyarakat desa mekarmanik. Jarak antara dusun di Desa Mekarmanik relatif tidak dekat, hal ini berdampak terhadap kehidupan masyarakat dalam mendapatkan pekerjaan.

LMDH Tani Mukti Giri Jaya merupakan wadah bagi masyarakat desa hutan untuk pengembangan pengelolaan hutan. Lembaga tersebut menjembatani masyarakat dalam perizinan pengelolaan lahan di kawasan hutan milik perum perhutani melalui kerjasama antara perum perhutani dengan LMDH. Terdapat enam kelompok tani yang tergabung dalam LMDH Tani Mukti Giri Jaya, diantaranya lima kelompok tani komoditas kopi dan satu kelompok tani komoditas bambu.

\section{Aspek Pemanfaatan Hutan}

\section{Faktor Pendorong}

Dari berbagai momentum dari sekala dunia hingga nasional berdampak terhadap keberlangsungan di Desa Mekarmanik dalam pengelolaan hutan yang termasuk kedalam Kawasan Bandung Utara (KBU) terdapat sekitar 596,40 ha luasan hutan di desa tersebut atau sekitar $50 \%$ luas desa tersebut 
merupakan hutan. Hal ini perlu dimanfaatkan untuk melahirkan kebermanfaatan bersama bagi masyarakat. Lembaga Masyarakat Desa Hutan lahir untuk berkerja sama dengan pihak pemerintah dan masyarakat desa hutan dalam mengelola lahan pemerintah yang berada di kawasan tersebut. Salah satu inisiator awal pendirian LMDH di Desa Mekarmanik yaitu Pak Tamid yang merupakan salah satu mantan pegawai Perum Perhutani sekaligus warga Desa Mekarmanik.

Menurut Utami (2015), pengelolaan hutan bersama masyarakat bertujuan untuk mengembangkan kapasitas dengan memberikan akses kepada masyarakat desa hutan dalam memanfaatkan kawasan hutan guna menjamin ketersediaan lapangan kerja bagi masyarakat desa hutan untuk memecahkan persoalan ekonomi dan sosial yang terjadi di masyarakat. Dengan adanya kegiatan tersebut, diharapkan dapat meningkatkan kesejahteraan masyarakat desa hutan melalui pemanfaatan sumber daya hutan secara optimal dengan tetap menjaga kelestarian fungsi hutan dan lingkungan hidup. Maka, idealnya peran LMDH dapat membantu keterlibatan masyarakat untuk terlibat langsung dalam pengelolaan hutan.. Maka, idealnya peran
LMDH dapat membantu keterlibatan masyarakat untuk terlibat langsung dalam pengelolaan hutan.

Noviati et al (2014), regenerasi pengurus dan penataan kembali manajemen kelembagaan dibutuhkan untuk mewujudkan lembaga sosial kemasyarakatan yang kokoh dan mandiri sesuai dengan tujuan pokok dan fungsi dari LMDH serta pentingnya keterlibatan aktif Perum Perhutani khususnya dalam membantu mengatasi keluhan yang dirasakan oleh LMDH dalam melakukan pemeliharaan dan pengawasan sumber daya hutan. Peranan dari pihak yang bersedia menjadi pendamping LMDH juga diperlukan dalam mengawasi dan melakukan pembimbingan melalui kegiatan positif dan solutif demi terwujudnya LMDH yang aktif dan produktif.

Kondisi LMDH Tani Mukti pada saat awal tahun 2020 sedang mengalami kekosongan kepemimpinan di dalam organisasi tersebut. Hal ini disebabkan ketua LMDH yang sedang menjabat pada saat itu meninggal dunia. Selain itu, ada saran dari masyarakat kepada pihak kantor desa untuk memfasilitasi pemilihan ketua LMDH untuk membuat panitia pemilihan Ketua LMDH dengan melibatkan elemen masyarakat. Beberapa 
aspirasi telah disampaikan oleh masyarakat desa terhadap pemangku kepentingan di kantor desa.

Terdapat saran dari masyarakat untuk merombak keseluruhan pengurus LMDH agar lembaga tersebut terganti secara hierarki dari ketua hingga kepengurusan internal. Selain itu, terkait dukungan secara moral melalui tokoh masyarakat juga mendorong keberlangsungan lembaga tersebut.

Pada kongres kehutanan dunia dapat membawa sudut pandang baru bagi pemangku kepentingan di Indonesia, lalu program pemerintah dengan merangkul masyarakat dalam mengelola hutan agar masyarakat dapat memanfaatkan lahan dan terlahirnya sumber perekonomian masyarakat dan hutan yang berada di bawah kewenangan pemerintah dapat terbantu dari segi kelestarian hutan tersebut oleh masyarakat sekitar. LMDH Tani Mukti Giri Jaya menjadi salah satu lembaga yang berperan dalam program tersebut, terjadinya kekosongan ketua lembaga dan aspirasi masyarakat terhadap kantor desa untuk digelar pemilihan ketua LMDH dengan demokratis serta mempertimbangkan pihak-pihak pemangku kepentingan di Desa Mekarmanik dalam pemilihan Ketua LMDH Tani Mukti Giri Jaya.
Maka dari itu, seluruh potensi kawasan hutan yang berada di kawasan Desa Mekarmanik dapat dimanfaatkan oleh masyarakat dengan tetap menjaga nilai aturan yang telah ditetapkan oleh berbagai pihak yang terlibat.

\section{Dampak}

Dampak yang diharapkan dari program PHBM bagi masyarakat, lingkungan, dan keberlangsungan negara tentu harapan yang positif bagi seluruh aspek tersebut. Meskipun seluruh wilayah tidak dapat dipastikan menuju titik ideal untuk suatu dampak yang positif, tidak dapat dipungkiri terdapat wilayah yang mengalami dampak positif dari program PHBM. Seperti contohnya di Desa Kemiri, Kecamatan Panti melalui penelitian yang dilaksanakan oleh Puspaningrum (2011) Pelaksanaan Program PHBM di Desa Kemiri membawa dampak terhadap masyarakat desa hutan yaitu perubahan sosial masyarakat desa hutan.

Dampak nyata yang terjadi wilayah hutan di Desa Mekarmanik semenjak dimulainya program pengelolaan hutan bersama masyarakat. Salah satunya peningkatan jumlah komoditas tanaman kopi di wilayah hutan tersebut. Dampak bagi masyarakat yang 
mengelola lahan di yaitu terjadi peningkatan kesejahteraan serta dampak bagi masyarakat yang tidak mengelola lahan yaitu adanya peluang mendapatkan pekerjaan sebagai buruh yang bekerja di lahan petani kopi hutan. Perubahan ekonomi masyarakat desa hutan mengakibatkan perubahan struktur pada masyarakat desa hutan yang mengelola lahan di hutan karena dapat berpengaruh bagi seluruh elemen masyarakat. Namun, pada pelaksanaannya terdapat beberapa rintangan untuk mewujudkan harapan pengelolaan hutan bersama masyarakat karena diperlukannya pemahaman dari seluruh aspek yang berperan dalam menjaga peranan masing-masing.

Selain dampak positif yang terjadi, terdapat dampak yang diakibatkan dari kurangnya komunikasi dan pemahaman antar pelaku di lapangan, salah satu contohnya yaitu konflik sosial yang terjadi di kalangan masyarakat. Contohnya, terdapat beberapa masyarakat yang merupakan pengrajin kerajinan bambu, mereka mengambil bambu dari hutan. Lokasi tanaman bambu berada di kawasan sungai, di sisi lain terdapat petani kopi yang memperluas lahan kebun kopi untuk dijadikan lahan perkebunan kopi dengan menebang beberapa kawasan bambu. Maka, terdapat perbedaan pendapat dalam memanfaatkan kawasan hutan tersebut antara masyarakat petani kopi dan masyarakat pengrajin bambu. Kejadian tersebut dapat terhindarkan dan sesuai dengan pendapat Albornoz, et al (2005) berpendapat bahwa cara-cara pengelolaan hutan yang baik dapat memberi manfaat bagi warga antara lain meningkatkan akses dan kendali warga terhadap sumber daya hutan, mendidik warga tentang hak-hak mereka atas hutan, melindungi akses hutan warga, menciptakan lingkungan pendukung untuk mengembangkan usaha dan konservasi hutan, meningkatkan pemerataan manfaat hutan bagi masyarakat, dan mendukung pembangunan pasar hilir.

Nugroho (2011) mengungkapkan harapan PHBM untuk menunjukan arah pengelolaan sumberdaya hutan dengan memadukan aspek-aspek ekonomi, ekologi dan sosial secara proporsional, sementara harapan LMDH untuk menjadikan LMDH mandiri sebagai salah satu syarat bagi proses pembangunan berkelanjutan di sektor pengelolaan sumber daya hutan dan peningkatan taraf hidup masyarakat mendapat berbagai kendala, seperti adanya kesenjangan antara konsep dan implementasinya juga 
dipengaruhi oleh faktor-faktor pendorong dan penghambat terwujudnya LMDH yang mandiri. Aspek tersebut bila dikaitkan dengan kondisi hutan di Desa Mekarmanik yang beberapa wilayah tertentu terdapat nilai serta fungsi antara masing-masing bagian perlu dijaga oleh seluruh pihak yang terlibat. Salah satu contohnya seperti fungsi tanaman bambu di bantaran sungai untuk menjaga kualitas sungai perlu diperhatikan agar tidak terjadi kesalahpahaman antar masyarkat yang memanfaatkan hutan tersebut.

\section{Kendala}

Terdapat beberapa kendala yang terjadi di LMDH Tani Mukti Giri Jaya yang dibagi kedalam beberapa waktu yang berbeda, yaitu kendala pada saat LMDH masa kini dan pada saat masa lampau. Dalam penelitian yang dilaksanakan oleh Noviati et al (2014) di Desa Donorejo salah satu kendala yaitu adanya hambatan internal dan eksternal. Anggota LMDH terpengaruh dari yang dialaminya seperti intensitas keterbukaan pihak pemangku kepentingan terhadap anggotanya, hal ini bertujuan untuk meminimalisir rasa ketidakpercayaan bagi anggotanya. Para petani serta buruh tani di LMDH Tani Mukti Giri Jaya perlu berkomunikasi dengan pengurus LMDH, hal ini agar miss komunikasi antar internal lembaga tidak terjadi. Namun, kendala yang terjadi pada saat ini yaitu dalam membangun komunikasi tersebut, petani cenderung kurang berani untuk mengekspresikan ketika dirangkul oleh pengurus LMDH.

Tidak dapat dipungkiri, hasil dari kepengurusan di masa sebelumnya LMDH berdampak terhadap keberlangsungan LMDH saat ini, karena kepengurusan LMDH terdahulu kurang fokus terhadap internal pengurus. Meskipun LMDH Tani Mukti Giri Jaya pada saat kepengurusan sebelumnya kurang aktif dalam pengembangan internal pengurus, masyarakat desa hutan tetap dipersilahkan pengelolaan lahan di kawasan perum perhutani, dengan tetap menjalankan persyaratan yang diwajibkan oleh kedua belah pihak. Dalam kelembagaan masyarakat dibutuhkan prinsip dalam pengembangan sebagai pilar menuju proses peningkatan mutu lembaga tersebut.

Nugroho (2011) berpendapat bahwa prinsip-prinsip tersebut harus dijunjung tinggi, ditumbuh kembangkan serta dilestarikan oleh semua pelaku dan stakeholder yang berkaitan dengan kegiatan LMDH. Prinsip-prinsip yang 
diperlukan LMDH adalah sebagai berikut: demokrasi, partisipasi, transparansi, kuntabilitas, dan prinsip kebersamaan. Berdasarkan hasil dari penelitian tersebut, prinsip tersebut sangat penting dioptimalkan dalam keberlangsungan lembaga. Kurangnya beberapa prinsip di LMDH Tani Mukti Giri Jaya menjadi salah satu kendala pada saat LMDH kurang berfungsi sebagaimana mestinya seperti adanya pengembangan internal lembaga. Maka dari itu, komunikasi antara pihak-pihak pemangku kepentingan perlu ditingkatkan agar dapat meminimalisir kejadian lembaga yang kurang berfungsi dengan optimal.

Noviati et al (2014) berpendapat bahwa solusi dalam menyelesaikan permasalahan tersebut reorientasi dan pemahaman paradigma baru terkait LMDH agar masyarakat paham bahwa setiap individu berperan penting dalam memajukan eksistensi lembaga yang berdampak pada keberhasilan pembangunan daerah dan peningkatan taraf hidup masyarakat. Terdapat kaitan dari perjalanan dalam pemaknaan paradigma baru di LMDH Tani Mukti Giri Jaya.

Beberapa masyarakat Desa Mekarmanik cenderung kurang mempercayai pengurus LMDH yang dikelola oleh kalangan muda. Tidak dapat dipungkiri berbagai perspektif masyarakat terhadap kepengurusan baru LMDH yang situasinya mayoritas diurus oleh kalangan muda, menimbulkan rasa kurang kepercayaan. Namun, dalam menghadapi perspektif yang seperti itu pengurus lembaga tidak mempermasalahkan hal tersebut karena hal itu merupakan hak masyarakat dalam berpendapat. Hal ini menjadi suatu tantangan baru yang lahir untuk LMDH menunjukan kepada masyarakat untuk sadar keberadaan LMDH tidak hanya untuk membantu masyarakat yang memanfaatkan lahan di hutan.

Terkait dengan program yang dikeluarkan oleh Pemerintah yaitu Perhutanan Sosial yang didalamnya terdapat Kemitraan Kehutanan dalam bentuk KULIN KK, LMDH Tani Mukti Giri Jaya sedang dalam proses pemenuhan persyaratan KULIN KK tersebut. Dalam perjalanan untuk memenuhi persyaratan program tersebut, petani seringkali enggan hingga sulit untuk memberikan identitas KTP kepada LMDH Tani Mukti Giri Jaya. Hal ini disebabkan pada saat waktu sebelumnya petani sudah pernah memberikan identitas KTP. Namun, terdapat 
keterhambatan pada kepengurusan sebelumnya dalam hal pengurusan KULIN KK. Beberapa kali masyarakat desa hutan yang mengelola lahan di kawasan perum perhutani sudah memberikat identitas kepada kepengurusan LMDH sebelumnya. Maka, salah satu penyebab berbagai kendala yang terjadi saat ini berkorelasi dengan pada saat kepengurusan sebelumnya.

\section{Aspek Kelembagaan}

\section{Status hutan dan lahan di lokasi}

Pemerintah memberikan akses legal kepada masyarakat di dalam dan di sekitar hutan untuk mengelola sumber daya hutan dalam lima skema pengelolaan, yaitu hutan kemasyarakatan, hutan desa, hutan tanaman rakyat, kemitraan, serta hutan adat. Kawasan hutan lahan perum perhutani di Desa Mekarmanik tergabung ke dalam Kesatuan Pengelolaan Hutan (KPH) Bandung Utara yang membawahi Bagian Kesatuan Pengelolaan Hutan (BKPH) Manglayang Barat dan terdapat Resort Pemangku Hutan (RPH) Arcamanik yang bekerja sama dengan LMDH Tani Mukti Giri Jaya melalui pengelolaan hutan bersama masyarakat dan sedang berproses menuju perhutanan sosial skema kemitraan kehutanan.

Peraturan terkait Kemitraan Kehutanan telah tertuang di Peraturan Menteri Kehutanan nomor P.39/MenhutII/2013 tentang Pemberdayaan Masyarakat setempat melalui kemitraan kehutanan, Peraturan Menteri LHK No. P.83/2016 tentang Perhutanan Sosial, Permen LHK Nomor P.39/MENLHK/SETJEN/ KUM.1/ 6/2017 Tentang Perhutanan sosial di wilayah kerja Perum Perhutani.

Kemitraan kehutanan merupakan kerjasama pemanfaatan kawasan hutan antara masyarakat dengan pengelola hutan (KPH, Perhutani) atau pemegang izin pemanfaatan hutan (HPH, HTI). Kerjasama antara masyarakat setempat dengan Pengelola Hutan, Pemegang izin usaha pemanfaatan hutan/jasa hutan, pinjam pakai kawasan hutan, atau izin usaha industri primer hasil hutan.

Kelembagaan masyarakat dalam kemitraaan kehutanan adalah kelompok tani. Komoditi yang ditanam, hak dan kewajiban masing-masing pihak dan prosentasi bagi hasil pemanfaatan merupakan kesepakatan antara masyarakat dengan pengelola atau pemegang izin pemanfatan. Kesepakatan antara masyarakat dengan pengelola atau 
pemegang izin dituangkan dalam Naskah Kesepakatan Kerjasama (NKK) atau Perjanjian Kerjasama (PKS).

\section{Hak Atas Lahan}

Berdasarkan Permen LHK Nomor P.39/MENLHK/SETJEN/KUM.1/6/2017 Tentang Perhutanan sosial di wilayah kerja Perum Perhutani Pasal 1 disebutkan bahwa perhutanan sosial di wilayah kerja Perum Perhutani adalah sistem pengelolaan hutan lestari yang dilaksanakan dalam kawasan hutan negara yang dikelola oleh Perum Perhutani yang dilaksanakan oleh masyarakat sebagai pelaku utama untuk meningkatkan kesejahteraannya, keseimbangan lingkungan dan dinamika sosial budaya dalam bentuk izin pemanfaatan hutan.

Pembagian hasil kerjasama antara Perum Perhutani dengan petani yang menggarap lahan Perum Perhutani di Desa Mekarmanik tertuang dalam pembagian 30\%: 70\%. Dalam rincian 30 $\%$ tersebut terbagi menjadi $16 \%$ untuk Perum Perhutani, 6\% untuk Pendapatan Naerah Bukan Pajak (PNBP), 4\% untuk Kelompok Tani Hutan (KTH), 2\% untuk LMDH Tani Mukti Giri Jaya, 2\% untuk Desa Mekarmanik.

\section{Nilai Sosial-Budaya}

Secara administratif Hutan yang terdapat di Desa Mekarmanik bernama Hutan Arcamanik. Hutan Arcamanik serta masyarakat yang tinggal disekitar sampai saat ini menjalankan prinsip budaya sunda dan konservasi alam. Terdapat beberapa bukti peninggalan peradaban Kerajaan Arcamanik pada zaman dahulu yang berlokasi di Desa Mekarmanik. Hasil penelitian seorang geologiwan Belanda bernama R.D.M Veerbek tahun 1883, bahwa di Pasir Pamoyanan wilayah hutan Arcamanik ditemukan dua patung Ciwa Mahadewa, satu Patung Dewi Durga dan sebuah alas.

Terdapat tiga konsep hutan di Desa Mekarmanik:

a. Hutan Titipan

Berlokasi di puncak dan lereng terjal Gunung Palasari serta Pasir Malang, di kawasan ini masyarakat tidak melakukan aktivitas pengambilan kayu dan masyarakat luar tidak memanfaatkan lahan tersebut. Nilai konservasi yang tinggi menjadi salah satu penyebab kawasan tersebut tidak dimanfaatkan oleh siapapun.

b. Hutan Tutupan

Masyarakat umum, institusi dan tentunya masyarakat desa dapat menitipkan beberapa pohon dengan 
catatan untuk tujuan penelitian, konservasi, nilai adat menanam pohon untuk waktu yang akan datang agar terawat hingga generasi berikutnya, serta edukasi keragaman hayati. Terdapat 23 jenis bambu di lokasi tersebut kurang lebih seluas 19 ha berupa hutan penelitian Arcamanik. Terkait dengan ketentuan tersebut kawasan hutan lindung bambu, sebenarnya masyarakat dapat mengelola dengan cara memenuhi persyaratan dan berkoordinasi dengan dinas. Namun, sampai saat ini belum terdapat upaya antara kedua belah pihak dan tidak terjadi masyarakat yang melanggar untuk memanfaatkan dari dalam hutan lindung tersebut.

c. Hutan Garapan

Kawasan ini merupakan lahan yang digarap oleh masyarakat desa hutan untuk digarap. Mayoritas masyarakat menanam komoditas kopi untuk memanfaatkan lahan ini.

\section{Keberadaan Lembaga}

Keberadaan LMDH Tani Mukti Giri Jaya di Desa Mekarmanik berada dalam garis koordinasi dengan pihak kantor desa. Terdapat 6 desa pilar yang terdapat di desa mekarmanik yaitu BPD, LPMD, Karang Taruna, PKR, MUI, dan LMDH. Beberapa pilar tersebut memiliki kedudukan yang berbeda, seperti contohnya karang taruna berada di bawah jalur intruksi kantor desa. Namun, sampai saat ini belum tercapai rencana kolaborasi antara LMDH dan pilar-pilar tesebut.

Kedudukan LMDH merupakan salah satu contoh yang berada di jalur koordinasi dengan pihak kantor desa. Ketika terdapat urusan yang menyangkut Hutan yang berada di Desa Mekarmanik, LMDH Tani Mukti Giri Jaya menjadi lembaga terdapat untuk mengelola hal tersebut karena hal tersebut menjadi salah satu kewenangan dari LMDH kondisi tersebut sesuai dengan pendapat Awang, et al (2008) bahwa Lembaga Masyarakat Desa Hutan (LMDH) adalah satu lembaga yang dibentuk oleh masyarakat desa yang berada di dalam atau disekitar hutan untuk mengatur dan memenuhi kebutuhannya melalui interaksi terhadap hutan dalam konteks sosial, ekonomi, politik, dan budaya.

\section{Rencana LMDH Tani Mukti Giri Jaya Rencana Jangka Pendek}

1. KULIN KK

Terdapat beberapa skema dalam pelaksanaan perhutanan sosial di wilayah kerja Perum Perhutani diantaranya yaitu skema Kemitraan Kehutanan dalam bentuk KULIN KK atau Pengakuan 
Perlindungan Kemitraan Kehutanan dan IPHPS (Izin Pemanfaatan Hutan Perhutanan Sosial di hutan lindung dan hutan produksi). Saat ini, LMDH Tani Mukti Giri Jaya belum mencapai skema KULIN KK dan skema tersebut dijadikan rencana untuk keberlangsungan $\mathrm{LMDH}$ tersebut.

Kulin KK memiliki beberapa keuntungan salah satunya jangka waktu dalam perjanjian yang lebih lama. Seperti contoh kasus di wilayah Madura, yaitu LMDH Kangean Barat telah mengajukan permohonan KULIN KK kepada kementrian kehutanan dengan harapan legalitas masyarakat yang tergabung dalam LMDH akan memiliki kekuatan hukum dan LMDH dapat mengelola perhutanan sosial dengan perjanjian selama 35 tahun dengan memakai pola kemitraan kehutanan sesuai dengan aturan. Maka dari itu, petani di Desa Mekarmank dan LMDH Tani Mukti Giri Jaya sedang dalam perjalanan untuk menyelesaikan perizinan KULIN KK tersebut.

\section{Ruang Diskusi}

Pentingnya membangun komunikasi dalam implementasi seluruh rencana pihak yang terlibat dalam meningkatkan kualitas internal lembaga dibutuhkan tempat untuk berkomunikasi.
Ruang Diskusi antara LMDH dan petani menjadi salah satu rencana untuk meningkatkan kemajuan lembaga. Saat ini LMDH Tani Mukti Giri Jaya telah memiliki ruangan sekretariat untuk penunjang keberlangsungan lembaga, Namun jika petani hutan berdiskusi di sekretariat mereka cenderung kurang berpartisipasi . Maka, dalam menggapai tujuan untuk membangun komunikasi yang dinamis LMDH Tani Mukti Giri Jaya berencana untuk membuat saung di setiap wilayah kebun KTH untuk tempat bersilaturahmi dan berdiskusi antara LMDH dan KTH.

\section{Pembuatan Berita Acara}

Pembuatan Berita Acara pada saat sharing hasil pemanfaatan hutan. Pada saat pembagian tersebut, sering terjadi polemik perbedaan sudut pandang antara pihak perhutani dan pihak kelompok tani hutan. Selain adanya kuitansi pembayaran pada saat sharing, LMDH Tani Mukti Giri Jaya membuat berita acara pada setiap sharing dilaksanakan. Hal ini bertujuan untuk meminimalisir miss komunikasi antara Kelompok Tani Hutan dan Perhutani dengan cara menuliskan secara jelas jumlah luasan yang di garap oleh petani dan dituliskan jumlah hasil panen yang didapatkan dalam sewaktu panen. Terdapat hasil dari 
inovasi

untuk

mengadakan

pemberitahuan berita acara karena setiap petani dalam mengelola wilayah kebun masing-masing memiliki perbedaan dalam perawatan untuk tanaman kopi. Di sisi lain, keberlangsungan bisnis dunia pertanian bersifat tentatif, beberapa faktor internal petani berpengaruh untuk keberlangsungan hasil panen kebun.

\section{Rencana Jangka Panjang}

LMDH Tani Mukti Giri Jaya berencana untuk memantik lahirnya pusaran ekonomi bagi masyarakat desa hutan yang memanfaatkan lahan di dalam hutan maupun yang tidak memanfaatkan di dalam hutan melalui komoditas kopi. Hal ini disebabkan karena kopi dapat ditambahkan nilai yang beranekaragam seperti contohnya dapat menyerap tenaga kerja bagi masyarakat desa hutan yang tidak menggarap lahan di hutan, dapat menyerap tenaga kerja sebagai berikut: buruh petik, buruh angkut, penyortir biji (non-kering), pengupas biji kopi, penjemur kopi, penyortir biji kering, pemanggang biji kopi, pemasaran kopi, dan kedai kopi.

\section{KESIMPULAN DAN SARAN Kesimpulan}

1. LMDH Tani Mukti Girijaya telah didirikan pada tahun 2005, seiring berjalannya waktu pada tahun 2011 LMDH tersebut telah dibuat akta pendirian lembaga. Kurangnya intensitas kepengurusan internal LMDH Tani Mukti Giri Jaya menyababkan lembaga tersebut kurang berjalan dengan semestinya, Namun masyarakat tetap dapat memanfaatkan lahan hutan di kawasan tersebut dan berbagai perjanjian antara perum perhutani dengan masyarakat tetap berjalan. Pada tahun 2020 telah terselenggarakan pemilihan ketua LMDH Tani Mukti Girijaya yang difasilitasi oleh kantor desa dengan melibatkan Asper BKPH Manglayang Barat, KSS. Kelola Sosial BDU, KRPH Arcamanik, Ketua BPD Desa Mekarmanik, Tokoh Masyarakat Desa, dan Pendamping LMDH yang dihadiri oleh masing-masing anggota Kelompok Tani Hutan yang tergabung kedalam LMDH Tani Mukti Giri Jaya. Pemlihan ketua tersebut sekaligus merombak seluruh internal LMDH Tani Mukti sesuai dengan kebutuhan lembaga.

2. Masyarakat di sekitar hutan Desa Mekarmanik yang tergabung dalam LMDH Tani Mukti Giri Jaya, berkerjasama dengan perum perhutani 
melalui program yang sebelumnya yaitu PHBM dan program Perhutanan Sosial yang sedang dalam proses penyelesaian SK KULIN KK berdampak terhadap masyarakat untuk mendapatkan akses pengelolaan lahan di lahan kerja perum perhutani seluas 594,6 hektar. Hingga saat ini, pemanfaatan lahan kehutanan oleh LMDH dengan menanam tanaman kopi. Komoditas kopi dijadikan pilihan dengan pertimbangan tanaman tersebut dapat bermanfaat bagi lingkungan untuk meminimalisir timbulnya erosi karena dapat membantu menahan tanah dan air. Hal ini membuat tanaman tersebut memiliki fungsi konservasi yang sama dengan tanaman hutan lainnya dan hasil panen kopi dapat dimanfaatkan oleh masyarakat yang tidak menanam tanaman kopi di hutan.

3. Rencana LMDH Tani Mukti Giri Jaya terbagi dalam rencana jangka pendek dan rencana jangka panjang. Rencana jangka pendek saat ini fokus untuk menyelesaikan persyaratan KULIN KK, pembuatan ruang diskusi di setiap blok kebun kopi, dan pembuatan berita acara pada saat pembagian pemanfaatan hasil hutan. Rencana jangka panjang dari LMDH agar dapat memantik perputaran arus ekonomi bagi masyarakat yang memanfaatkan lahan di kawasan hutan perum perhutani dan bagi masyarakat yang tidak memanfaatkan lahan di hutan, merupakan salah satu rencana jangka panjang yang direncanakan oleh LMDH Tani Mukti Giri Jaya melalui komoditas kopi.

\section{Saran}

1. Rutin untuk mengevaluasi ulang data lembaga dalam jangka waktu yang tertentu ketika data anggota serta luas lahannya telah terpenuhi.

2. Membuat sarana informasi online yang terstruktur dan sistematis dalam pemberian informasi LMDH Tani Mukti Giri Jaya. Seperti membuat dan menerapkan Standar Operasional Prosedur (SOP) untuk akun resmi lembaga secara online di sosial media maupun website.

3. Perlu penelitian lebih lanjut secara kuantitatif mengenai dampak ekonomi dan sosial budaya Program Perhutanan Sosial melalui LMDH Tani Mukti Giri Jaya di Desa Mekarmanik terhadap masyarakat Desa Mekarmanik.

4. Menjaga komunikasi dinamis antara pengurus lembaga dan anggota 
kelompok tani melalui diskusi hingga

rencana terealisasi.

\section{DAFTAR PUSTAKA}

Albornoz, M. A., Becker, M., Cahyat, A., Cronkleton, P., Jong, W., Evans, K., \& Wollenberg, E. (2007). Menuju Kesejahteraan dalam Masyarakat Hutan: Buku Panduan untuk Pemerintah Daerah. Bogor: Cifor

Anantanyu, S. (2011). Kelembagaan petani: peran dan strategi pengembangan kapasitasnya. Jurnal Sepa, 7(2), 102-109.

Ekawati, S., Budiningsih, K., Sylviani, S. E., \& Hakim, I. (2015). Kajian tinjauan kritis pengelolaan hutan di Pulau Jawa. Policy Brief, 9(1).

Farida, U. (2013). Pengaruh aksesibilitas terhadap karakteristik sosial ekonomi masyarakat pedesaan Kecamatan Bumijawa Kabupaten Tegal. Jurnal Wilayah dan Lingkungan, 1(1), 49-66.

Maryudi, A., \& Nawir, A. A. (2018). Hutan Rakyat di Simpang Jalan. UGM PRESS.

Munawar, A. (2019). Potensi Wisata Alam dalam Kawasan Hutan, Pemanfaatan dan Pengembangan: Studi Kasus di Kabupaten Maros Sulawesi Selatan. Inti Mediatama

Noviati, A., Banowati, E., \& Indrayati, A. (2014). Optimalisasi Peran Lembaga Masyarakat Desa Hutan
(Lmdh) Bangun Dalam

Meningkatkan Partisipasi Petani Di Desa Donorejo. Geo-Image, 3(1).

Nugroho, S. S. (2011). Pengelolaan

Hutan Bersama Masyarakat

(PHBM) Melalui Penguatan

Lembaga Masyarakat Desa Hutan

(LMDH)(Kajian Hukum Penguatan

Kapasitas LMDH dan Peningkatan

Efektivitas PHBM di Desa Dampit,

Kecamatan Bringin, Kabupaten Ngawi). Jurnal Sosial, 12(2), 94107

Puspaningrum, D. (2011). Pelembagaan

Program Pengelolaan Sumberdaya

Hutan Bersama Masyarakat

(PHBM) dan Dampaknya Bagi Masyarakat Desa Hutan. JSEP (Journal of Social and Agricultural Economics), 5(3), 1-14.

Rosmaladewi, O., Danuwikarsa, I., Robana, R., \& Pranadikusumah, P. (2019). Forest Village Community Empowerment through Multi-stake holder Partnership Program to form Sustainable Green Forests and Disaster Preparedness in Garut. In IOP Conference Series: Earth and Environmental Science (Vol. 298, No. 1, p. 012036). IOP Publishing.

Utami, N. N. (2015). Pengelolaan Hutan Bersama Masyarakat Ditinjau dari Perspektif Assets Based Community Development. Share: Social Work Journal, 5(2). 